\title{
Effect of Feed Restriction on Performance and Nutrient Digestibility in Ram Lambs
}

\author{
B. Sivanagendra Babu, M.V.A.N. Suryanarayana*, E. Raghava Rao and P. Asha Latha \\ Sri Venkateswara Veterinary University, Livestock Research Station, \\ Garividi-535101 (A P), India \\ *Corresponding author
}

\section{A B S T R A C T}

\begin{tabular}{|l|}
\hline K e y w o r d s \\
$\begin{array}{l}\text { Feed restriction, } \\
\text { Realimentation, } \\
\text { Compensatory } \\
\text { growth, Nutrient } \\
\text { utilization. }\end{array}$ \\
\hline Article Info \\
\hline $\begin{array}{l}\text { Accepted: } \\
\text { 04 July 2017 } \\
\text { Available Online: } \\
\text { 10 September } 2017\end{array}$ \\
\hline
\end{tabular}

\section{Introduction}

In most parts of the world, livestock production systems mainly depend upon on natural vegetation of range and farm lands. Seasonal fluctuations cause a frequent restriction both in terms of quality and quantity (Anya et al., 2008).

The available feed does not meet the nutrient requirements of the animals. Livestock subjected to a period of under nutrition often exhibits a very high growth rate during subsequent realimentation (Abegaz et al., 1996).
This phenomenon is called Compensatory growth. There are many reports saying that compensatory growth may be influenced by genetic factors, age of the animals at which the restriction was imposed, severity and duration of restriction, the quality of realimentation diet and duration of refeeding (Benschop, 2000; Lawrence and Fowler, 2002).

It was reported that feed restriction has a significant effect on the total lipids, total protein, globulins (Abdalla et al., 2014) in 
sheep. Feed restriction decreased the portion of live weight of the dissectible fat, internal fat, subcutaneous fat liver, lung and other visceral organs and upon realimentation it was associated with greater daily gain and less internal fat (Dashtizadeh et al., 2008; Kamalzadeh and Aouladrabiei, 2009; Shadnoush et al., 2011; Sami et al., 2013; Abouheif et al., 2015).

The objective of the present study was to quantify the influence of different feeding regimes on blood biochemical parameters and carcass characteristics in ram lambs.

\section{Materials and Methods}

A growth and a digestion trial were carried out at the Livestock Research Station, Garividi, Andhra Pradesh and chemical analysis at Animal Nutrition laboratory at NTR College of Veterinary Science, Gannavaram.

The chemical composition of feed ingredients was determined (AOAC, 2007) and the cell-wall constituents by Van Soest et al., (1991). Hemi-cellulose was calculated as the difference between NDF and ADF.

The experiment was carried out for a period of 8 weeks and 4 weeks for restricted and realimentation, respectively, in a CRD model. A 12 week growth trial (8 weeks restriction phase and 4 weeks re-alimentation phase) was conducted using 32 ram lambs (ave. 3 months age) randomly divided into 4 groups with 8 lambs in each group and was allotted to one of the following dietary regimes in which feed restriction was followed at 4 levels viz., $0 \%$ (control; $\left.\mathrm{T}_{1}\right), 10 \%\left(\mathrm{~T}_{2}\right), 20 \%\left(\mathrm{~T}_{3}\right), 30 \%\left(\mathrm{~T}_{4}\right)$ level. Restricted phase was followed for 8 weeks followed by re-alimentation phase for 4 weeks. Body weights were recorded at weekly intervals.
All the sheep were housed in groups in 4 different sheds and are fed under intensive system (ICAR 2013). In both the phases, the weekly body weights along with the daily feed offered and feed left over were recorded. The concentrate mixture $(\%)$ contained 50, 29.5, 18.5 and 0.5 parts for Maize, DORB, GNC, mineral mixture and salt, respectively. All the animals were fed with Subabul leaves as green fodder ad libitum.

During the last 7 days of the trial in both restriction phase and re-alimentation phase, digestibility trial was conducted. The daily feed intake was recorded. The faeces were collected in faecal bags from 6 sheep in each treatment of all the 4 treatments for every 3 hours in a day. The faeces collected were oven-dried for a period of 18 hours at a temperature of about $105^{\circ} \mathrm{C}$ and weighed daily. At the end of the collection period, the faecal samples collected from each treatment per day were pooled, ground and thoroughly mixed to obtain a homogenous mixture. Samples of faeces were subjected to proximate analysis (AOAC, 2007) and the data was subjected to one -way classification of analysis of variance (Snedecor and Cochran, 1989) and the means were tested by least significant difference.

\section{Results and Discussion}

The proximate composition (\%) of feed ingredients were $91.8,92.5$ and $91.7 ; 96.5$, $82.9,93.5 ; 9.5,14.5$ and $38.2 ; 2.1,1.6$ and $2.9 ; 2.7,16.8$ and $8.1 ; 82.2,50.4$ and 44.3 ; $3.5, \quad 17.5$ and $6.5 ; 0.56,2.3$ and 4.5, respectively for $\mathrm{DM}, \mathrm{OM}, \mathrm{CP}, \mathrm{EE}, \mathrm{CF}, \mathrm{NFE}$, TA and AIA for maize, de-oiled rice bran, Groundnut cake.

The cell wall constituents (\%) of feed ingredients were $17.9,35.8$ and $31.3 ; 9.7$, 19.5 and $19.8 ; 8.2,16.3$ and $11.5 ; 6.7,7.5$ and $13.8 ; 3.1,6.9$ and $4.2 ; 0.9,3.5$ and 2.2 , 
respectively for NDF, ADF, hemi-cellulose, cellulose, ADL and silica for maize, de-oiled rice bran, groundnut cake.

The proximate composition (\%) of concentrate mixture was 90.1(DM), 17.2 (CP), 3.6 (EE), 8.3 (CF), 9.5 (TA), 90.5 (OM) and 61.4 (NFE) and that of Subabul leaves was $36.9,22,5.6,16.6,11.5,88.5$ and 44.3 for $\mathrm{DM}, \mathrm{CP}, \mathrm{EE}, \mathrm{CF}, \mathrm{TA}, \mathrm{OM}$ and $\mathrm{NFE}$, respectively.

\section{Growth performance during feed restriction}

The initial weights $(\mathrm{kg})$ for the 4 groups were not significant among the treatments and the final weights $(\mathrm{kg})$ were significant $(\mathrm{P}<0.05)$ and the total weight gain was higher $(\mathrm{P}<0.05)$ for $T_{1}$ and it was in the order of $T_{1}>T_{2}>T_{3}>T_{4}$.

The average daily gain was decreased $(\mathrm{P}<0.05)$ from $\mathrm{T}_{1}$ to $\mathrm{T}_{4}$ with the increasing level of feed restriction. During restriction phase average daily gain was higher $(\mathrm{P}<0.05)$ and FCR was lower $(\mathrm{P}<0.05)$ in $\mathrm{T}_{1}$, respectively as compared to other groups. The average feed intake was higher for $T_{1}$ and it was in the order of $T_{1}>T_{2}>T_{3}>T_{4}$.

\section{Growth performance during realimentation phase}

The initial weight differ significantly $(\mathrm{P}<0.05)$ whereas the final weights were nonsignificant with total weight gain higher $(\mathrm{P}<0.05)$ for $\mathrm{T} 4$ and FCR was lowest $(\mathrm{P}<0.05)$ for this group (Table 1).

\section{Digestibility in restriction phase}

During restriction period, the digestibility coefficients (\%) for DM, CP, OM, NFE increased linearly $(\mathrm{P}<0.05)$ from $\mathrm{T} 1$ to $\mathrm{T} 4$ indicating maximum digestibility at $30 \%$ feed restriction. The digestibility of NDF, ADF were significant $(\mathrm{P}<0.05)$ among treatments and these values were higher for T4. The cellulose digestibility decreased linearly from $\mathrm{T} 1$ to T4 where as it was higher for T1 for hemicellulose

\section{Digestibility in realimentation phase}

Except for CP, DM \& ADF $(\mathrm{P}<0.05)$ none of the parameters were found to be significant. The digestibility coefficients of DM, CP, CF, $\mathrm{OM}$ and NFE increased linearly from $\mathrm{T} 1$ to $\mathrm{T} 4$.

It was observed from the results of the present study that the group of animals which were subjected to more feed restriction showed decreased weight gain, average daily gain, with higher feed conversion ratio. These results agree with Neto et al., (2011) where in it was reported that the animals subjected to $40 \%$ restriction, presented better feed conversion ratio $(\mathrm{P}<0.05)$ compared to the group without restriction. The feed conversion ratio (FCR) was higher for maximum restricted groups resulted from a low level of feeding regime and due to the probable reason that the restricted energy intake resulted in a lower weight gain as compared to the non-restricted animals.

The decreased live weight and average daily gain for the feed restricted groups as obtained in the present results are compared with those of Dashtizadeh et al., (2008) (Table 2).

During restriction phase, a decrease in total weight gain was observed in a down ward trend from $\mathrm{T}_{2}$ to $\mathrm{T}_{4}$ in the present findings. Shadnoush et al., (2011) also reported a similar trend which might be due to the reason that the maintenance requirements will decrease during under feeding. The reduction in growth performance may be due to the influence of the plane of nutrition of the restricted groups in the efficiency of feed utilization and the amount of feed required for maintenance. 
Table.1 The growth performance during restriction and realimentation phases

\begin{tabular}{|c|c|c|c|c|c|c|c|c|}
\hline \multirow[t]{2}{*}{ Parameter } & \multicolumn{4}{|c|}{ Restriction phase } & \multicolumn{4}{|c|}{ Realimentation phase } \\
\hline & $\mathrm{T} 1$ & $\mathrm{~T} 2$ & T3 & $\mathrm{T} 4$ & $\mathrm{~T} 1$ & $\mathrm{~T} 2$ & T3 & $\mathrm{T} 4$ \\
\hline Initial Wt $(\mathrm{kg})^{*}$ & $10.9 \pm 0.4$ & $11.1 \pm 0.4$ & $11.8 \pm 0.3$ & $11.5 \pm 0.3$ & $16.4^{\mathrm{a}} \pm 0.6$ & $15.8^{\mathrm{a}} \pm 0.5$ & $14.6^{\mathrm{a}} \pm 0.4$ & $13.9^{b} \pm 0.5$ \\
\hline Final Wt $(\mathrm{kg})^{*}$ & $16.4^{\mathrm{a}} \pm 0.5$ & $15.8^{\mathrm{a}} \pm 0.5$ & $14.6^{\mathrm{a}} \pm 0.4$ & $13.9^{b} \pm 0.4$ & $18.3 \pm 0.05$ & $18.5 \pm 0.4$ & $18.3 \pm 0.8$ & $19.2 \pm 0.5$ \\
\hline $\mathrm{ADG}(\mathrm{kg})^{*}$ & $0.13^{\mathrm{a}} \pm 0.004$ & $0.08^{\mathrm{a}} \pm 0.06$ & $0.05^{\mathrm{a}} \pm 0.01$ & $0.04^{\mathrm{ba}} \pm 0.03$ & $0.06^{\mathrm{d}} \pm 0.01$ & $0.09^{c} \pm 0.01$ & $0.13^{b} \pm 0.02$ & $0.2^{\mathrm{a}} \pm 0.01$ \\
\hline FCR* & $5.02^{b} \pm 0.18$ & $6.9^{b} \pm 0.60$ & $10.2^{\mathrm{a}} \pm 1.1$ & $11.4^{\mathrm{a}} \pm 1.1$ & $13.3^{\mathrm{a}} \pm 2.2$ & $8.7^{\mathrm{a}} \pm 0.80$ & $7.7^{\mathrm{b}} \pm 1.8$ & $4.8^{\mathrm{ab}} \pm 0.4$ \\
\hline ADFI (kg) & 0.67 & 0.57 & 0.51 & 0.47 & 0.76 & 0.77 & 0.78 & 0.86 \\
\hline
\end{tabular}

Table.2 The digestibility coefficients (\%) during restriction and realimentation phases

\begin{tabular}{|c|c|c|c|c|c|c|c|c|}
\hline \multirow[t]{2}{*}{ Parameter } & \multicolumn{4}{|c|}{ Restriction phase } & \multicolumn{4}{|c|}{ Realimentation phase } \\
\hline & $\mathrm{T} 1$ & $\mathrm{~T} 2$ & T3 & $\mathrm{T} 4$ & $\mathrm{~T} 1$ & $\mathrm{~T} 2$ & $\mathrm{~T} 3$ & $\mathrm{~T} 4$ \\
\hline Dry mater* & $82.0^{b} \pm 0.3$ & $83.6^{\mathrm{b}} \pm 0.8$ & $84.7^{b} \pm 0.3$ & $87.4^{\mathrm{a}} \pm 0.3$ & $85.9 \pm 0.06$ & $85.5 \pm 1.1$ & $87.7 \pm 1.3$ & $88.7 \pm 0.8$ \\
\hline Organic matter $*$ & $85.2^{c} \pm 0.06$ & $82.2^{\mathrm{d}} \pm 0.1$ & $87.2^{b} \pm 0.05$ & $88.4^{\mathrm{a}} \pm 0.04$ & $87.3^{\mathrm{b}} \pm 0.8$ & $85.0^{\mathrm{b}} \pm 0.4$ & $89.2^{\mathrm{a}} \pm 0.7$ & $90.3^{\mathrm{a}} \pm 1.1$ \\
\hline Crude Protein * & $84.5^{b} \pm 0.3$ & $85.6^{\mathrm{a}} \pm 0.5$ & $87.9^{\mathrm{a}} \pm 0.9$ & $86.1^{\mathrm{a}} \pm 0.8$ & $83.2^{\mathrm{b}} \pm 0.9$ & $87.3^{\mathrm{a}} \pm 0.8$ & $86.9^{\mathrm{ab}} \pm 0.7$ & $88.3^{\mathrm{a}} \pm 0.8$ \\
\hline Ether Extract & $83.4 \pm 1.3$ & $84.6 \pm 1.4$ & $82.0 \pm 2.2$ & $84.1 \pm 2.1$ & $85.8 \pm 1.2$ & $83.2 \pm 1.7$ & $82.9 \pm 2.6$ & $84.4 \pm 2.3$ \\
\hline Crude fibre & $54.2 \pm 0.5$ & $56.0 \pm 1.5$ & $52.3 \pm 1.3$ & $56.4 \pm 1.5$ & $54.9 \pm 0.6$ & $55.2 \pm 1.2$ & $57.3 \pm 0.4$ & $57.8 \pm 1.3$ \\
\hline $\mathrm{NFE} *$ & $81.8^{\mathrm{b}} \pm 0.4$ & $82.9^{b} \pm 0.7$ & $84.1^{\mathrm{a}} \pm 0.4$ & $85.6^{\mathrm{a}} \pm 0.7$ & $84.8^{\mathrm{ab}} \pm 0.6$ & $84.4^{\mathrm{b}} \pm 0.6$ & $85.3^{\mathrm{ab}} \pm 0.7$ & $86.9^{\mathrm{a}} \pm 0.9$ \\
\hline $\mathrm{NDF}$ & $58.1^{\mathrm{a}} \pm 0.6$ & $57.7^{\mathrm{a}} \pm 0.5$ & $55.1^{\mathrm{a}} \pm 0.8$ & $53.5^{b} \pm 1.4$ & $60.98 \pm 1.8$ & $61.4 \pm 1.5$ & $63.5 \pm 0.8$ & $65.9 \pm 1.2$ \\
\hline $\mathrm{ADF} *$ & $47.4 \pm 0.9$ & $47.1 \pm 0.7$ & $49.3 \pm 0.5$ & $48.4 \pm 0.8$ & $52.4^{\mathrm{a}} \pm 1.3$ & $49.2^{\mathrm{b}} \pm 0.7$ & $54.6^{\mathrm{a}} \pm 1.4$ & $54.4^{\mathrm{a}} \pm 1.4$ \\
\hline Hemi- cellulose & $58.2 \pm 1.1$ & $51.7 \pm 2.1$ & $51.8 \pm 1.3$ & $49.3 \pm 1.6$ & $59.3 \pm 0.2$ & $56.7 \pm 0.2$ & $55.9 \pm 0.1$ & $52.4 \pm 0.5$ \\
\hline Cellulose & $55.2 \pm 1.8$ & $50.3 \pm 0.7$ & $51.2 \pm 1.1$ & $49.3 \pm 2.1$ & $58.5 \pm 0.3$ & $55.1 \pm 0.2$ & $53.7 \pm 0.2$ & $51.3 \pm 0.2$ \\
\hline
\end{tabular}

abcd values in a row with different superscripts differ significantly $*(\mathrm{P}<0.05)$ 
These findings in the present study, suggest that feed requirements for maintaining body weight is not a constant function of body weight but may be altered by plane of nutrition. These observations are supported by several reports (Ferrel et al., 1986; Kamalzadeh and Aouladrabiei, 2009) which have shown that maintenance requirements decrease in response to levels of feed intake.

During feed restriction phase, the intake of dry matter, crude protein, neutral detergent fiber (NDF) and ether extract (EE) and nonfibrous carbohydrates and mineral matter were influenced by the applied restriction levels. The intake of these nutrients decreased as the restriction level increased (Neto et al., 2011). The smaller dry matter intake of the groups subjected to restriction resulted from the small quantity of feed offered and its intake was regulated as a function of dry matter intake ingested which also influenced the reduction in the intake of the other nutrients. Similar findings were reported by Costa et al., (2007) in heifers. The decrease in total weight gain in the present findings correlates with the results reported by Sami et al., (2013).

As the restriction level increased, feed conversion ratio also increased with a corresponding decrease in ADG in the present study (Abhouheif et al., 2013). The loss in the weight during restriction phase et al., in the present study also correlates with Kabbali et al., (1992) and Dashtizadeh et al., (2008). During feed restriction depending upon the severity of restriction, proteins are mobilized first followed by fats and this contributed to a body weight loss (Al-selbood, 2009).

During realimentation, it was observed from the results that the animals that were more restricted recouped faster due to a physiological impulse called Compensatory gain (Suryanarayana and Siva Prasad, 2014 ;
Ford and Park, 2001). They reported that during compensatory growth, the metabolism of the animal continues to adjust to a low feed ingestion and the basal energy metabolism continues to be low and increases slowly adjusting to the new feeding regime and so the utilization of energy and protein was more efficient.

Decreased maintenance cost, increased feed intake, increased efficiency of growth, genetic back ground and in some instances increased digesta load have been implicated as the key mechanisms in the compensatory growth phenomenon (Ryan, 1990; Benschop, 2000; Hornick et al., 2000; Joemat et al., 2004).

The digestibility coefficient (\%) of all nutrients showed an increasing trend as the feed restriction increased which could be due to a probable reason of more retention of the feed or low passage rate in the rumen, more enzymatic and in turn microbial action. It was reported by Molina Alcaide et al., (2000); Kawashine et al., (2007); Abidi et al., (2009) that dietary constituents have either positive or negative influence on the digestibility. Crude protein concentration has a positive effect on dry matter intake whereas fibre fractions of diets depressed dry matter intake of animals. Digestibility is dependent on dry matter intake (DMI). Since these two dietary nutrient factors are involved during restriction period, the digestibility coefficients (\%) of all the nutrients showed an increased trend.

These factors contradict with the results obtained during re-alimentation phase. There is a positive relation between the digestibility of feeds and the intake. When the feeds are rapidly digested, the faster the digestive track is emptied and more space is available for the next meal. Some contradictions may be due to different restriction levels, different phases of restriction and re-alimentation and different breeds with different maturity ages. 
It can be concluded that the increase in the feed restriction upto $30 \%$ level in the diet resulted in improved performance in terms of growth, nutrient digestibility, carcass yield, reducing the cost $/ \mathrm{kg}$ gain and cost of production in ram lambs.

\section{References}

Abegaz, S., Tiyo, D. and Gizachew, L. 1996. Compensatory growth in Horro lambs of Ethiopia. In: Small Ruminant research and development in Africa. Proceedings of the Third Biennial Conference of the African Small Ruminant Research Network, UICC, Kampala, Uganda ILRI, Nairobi, Kenya 209-213PN.

Abidi, S., Ben Salem, H., Vasta, V. and Priolo, A. 2009. Supplementation with barley or spineless cactus (Opuntia ficusindica f. inermis) cladodes on digestion, growth and intramuscular fatty acid composition in sheep and goats receiving oats hay. Small Rumin. Res. 87, 9-16.

Abouheif, M., Al-Owaimer, A., Kraidees, M., Hassan Metwally and Shafey, T. 2013. Effect of restricted feeding and realimentation on feed performance and carcass characteristics of growing lambs. Rev. Brasi de Zootec. 42(2): 95101.

Al-Selbood, B.A. 2009. Effect of feeding program on performance and carcass characteristics of Najdi lambs. Ph.D. Thesis. King Saud University, Saudi Arabia.

Anya, M. I., Edet, G. D., Nsa, E. E. and Umoren, E. P. 2008. Evaluation of mineral composition of some forage legumes and grasses in tropical high forest zone of cross river state, Nigeria. Nigerian South-East Journal of Agricultural Economics and Extension 8(1\&2) 33-37.
AOAC, 2007. Official methods of Analysis $\left(18^{\text {th }}\right.$ Ed.) Association of Official Analytical Chemists, Washington, DC.

Benschop, D., 2000. Compensatory growth in ruminants: an overview. In: Cant, J (Ed.), Proceedings of the 2000 course in ruminant digestion and metabolism. The University of Guelph. PP: 1-16.

Costa, P. B., Quieroz, A. C., Rodrigues, M. T., Megalhaes, A. L. R., Costa, M. G., Toral, F.L.B., Carvalho, T. A., Monteiro, L., Zorzi, K. and Durate, M. S. 2007. Performance of dairy heifers under management compensatory growth supplementation with ionophore. Rev. Brasi de Zootec., 36 (2):461-470.

Dashtizadeh, M., Zamiri, M. J., Kamalzadeh, A. and Kamali, A. 2008. Effect of feed restriction on compensatory growth response of young male goats. Iranian Journal of Veterinary Research, Vol. 9, No. 2, Ser. No. 23.

Ferrell, C. L., Koong, L. J. and Nienaber, J. A. 1986. Effect of previous nutrition on body composition and maintenance energy costs of growing lambs. Brit. J. Nutr., 56:595-605.

Ford, J.A., Jr and Park, C.S. 2001. Nutritionally directed compensatory growth 333 enhances heifer development and lactation potential. $J$. Dairy Sci. 84 1669-1678

Hornick, J. L., van Eanaeme, C., Gerard, O., Dufrashe, I. and Istasse, L. 2000. Mechanisms of reduced and compensatory growth. Domestic Animal Endocrinology, 19: 121-132.

Indian Council of Agricultural Research. Nutrient requirements of sheep. 2013.

Joemat, R., Goetsch, A. L., Horn, G. W. Sahlu, T. Puchala,R,.Mina, B. R., Luoa, J. and Smuts, M. 2004. Growth in yearling meat goats' doelings with changing plane of nutrition. Small Rumin. Res. 53 127-135. 
Kabbali, A., Johnson, W. L., Johnson, D. W., Goodrichand, R. D. and Allen, C. E. 1992. Effects of compensatory growth on somebody component weights and on carcass and non-carcass composition of growing lambs. J. Anim. Sci., 70: 2852-2858.

Kamalzadeh, A. and Aouladrabiei, M. R. 2009. Effect of restricted feeding on intake, digestion, nitrogen, balance and metabolizable energy in small and large body sized sheep breeds. J. Anim. Sci. 22:667-673.

Kawashima. T., Sumamal, W., Pholsen, P., Chaithiang, R. and Terada, F. 2007.Comparative study on energy and nitrogen metabolism of Brahman cattle and sheep given ruzi grass hay with different levels of soybean meal. Jpn. Agric. Res. Quar. 41: 253-260.

Lawrence, T. L. J. and Fowler, V. R. 2002. Growth of farm animals 2nd Edn, CAB International, Cambridge. PP: 229-254.

Molina Alcaide, E., Martin Garcia, A. I. and Augilera, J. F. 2000. A comparative study of nutrient digestibility, kinetics of degradation and passage and rumen fermentation pattern in goats and sheep offered good quality diets. Livest. Prod. Sci. 64: 215-223.

Neto Gonzaga, S., Bezerra, L. R., Medeiros, M. A., Ferreira, E. C., Pimenta Filho,
Candido, E.P. and Oliveira, R. 2011, Feed restriction and Compensatory growth in Guzera females. Asi. - Austr. J. Anim. Sci. 24(6): 791-799.

Ryan, W.J., 1990.Compensatory growth in cattle and sheep. Nutr. Abstr. Rev. (Series B),

Sami, A., Shafey, T. and Abouheif, M. 2013. Growth rate of carcass, non-carcass and chemical components of restricted fed and re-alimented growing lambs. Int. J. Agri. Bio.15: 307-312.

Shadnoush, G. R., Alikhani, M., Rahmani, H. R., Edriss, M. A., Kamalzadeh, A., and Zahedifar. 2011. Effect of Restricted and re-feeding in growing lambs, Intake, Growth and Body Organs Devellopment. J. Anim. Vet. Adv 10(3): 280-285, 2011.

Snedecor, G. W., and Cochran, W. G. 1994. Statistical methods $\left(9^{\text {th }}\right.$ edition) Iowa state university press, IOWA, USA.

Suryanarayana, M.V.A.N., and Siva Prasad, B. 2014, Impact of feed Restriction and Compensatory Growth in Sheep. Int. J. Fd and Agric and Veterinary Sci. Vol. 4 (2) May-August, pp. 28-32.

Van Soest, P. J., Robertson, J. B. and Lewis, B. A. 1991. Methods for dietary fiber, neutral detergent fiber and non-starch polysaccharides in relation to animal nutrition. Dairy Sci. 74: 3583-3597.

\section{How to cite this article:}

Sivanagendra Babu, B., M.V.A.N. Suryanarayana, E. Raghava Rao and Asha Latha, P. 2017. Effect of Feed Restriction on Serum Biochemical Profile and Carcass Characteristics in Ram Lambs. Int.J.Curr.Microbiol.App.Sci. 6(9): 566-572. doi: https://doi.org/10.20546/ijcmas.2017.609.068 